\title{
Asphalt Production from Asbuton Rock by Extraction Using Weak Acid
}

\author{
Ivan Mery Devianto*, llyin Abdi Budianta, Bambang Heru Susanto, Mohammad Nasikin \\ Chemical Engineering Department, Faculty of Engineering, University of Indonesia, Depok 16424 \\ *Corresponding Author: ivandevian@hotmail.com
}

Copyright (C) 2013 Horizon Research Publishing All rights reserved.

\begin{abstract}
Utilization of natural asphalt in Indonesia has not been fully implemented. Asphalt can be obtained through extraction of asbuton rock using acid solution. Acid solution will dissolve the carbonate solids in asbuton to obtain asphalt. Weak acid solution can be used because it is economical and not too corrosive, such as formic acid, acetic acid, and carbonic acid. Forformic acid and acetic acid, batch extraction with agitation was performed at various temperature $\left(25-95^{\circ} \mathrm{C}\right)$, acid concentration $(1-10 \mathrm{M})$, and time. For carbonic acid, $\mathrm{CO}_{2}$ was injected into saline solution continuously and then ultrasound-assisted extraction was performed in batch system. Variations in the concentration of $\mathrm{NaCl}(0-0.5 \mathrm{M})$ and temperature $\left(25-110^{\circ} \mathrm{C}\right)$ was performed in this solution. Amount of dissolved solids was influenced by all these variables. FTIR analysis and specific gravity testing indicated the presence of carbonate solids in asbuton rock and asphalt product. Formic acid and acetic acid is able to dissolve more solids than carbonic acid because carbonic acid is weaker than the others. However, the use of carbonic acid is more beneficial because $\mathrm{CO}_{2}$ can be regenerated from solution and then it can be used again in the next process. Asphalt from this process can be used to mix asphalt.
\end{abstract}

Keywords Asbuton, Extraction, Carbonate Solid, Weak Acid

\section{Introduction}

Natural asphalt found only in few countries such as the United States, France, and Indonesia. Indonesia also has a great resource of natural asphalt, which is named Asbuton. This should be proud because Indonesia has reserves of natural asphalt is greater than other country. The reserves of asbuton may reach 677 million tons and able to provide for infrastructure in this country for up to 200 years to come [1]. However, those reserves have not be exploited to the fullest [2].

Based on the quality, asbuton is better than petroleum asphalt. Asbuton have higher stability than petroleum asphalt, so durability of asbuton becomes longer [1,3]. Petroleum asphalt only have the endurance for five years, while asbuton have the endurance of up to ten years. Moreover, infrastructure development needs are not going to stop anytime soon. Therefore, asbuton has a bright future opportunities to be launched and utilized for infrastructure in Indonesia.

One way to get asphalt from asbuton rock was extraction process. Development of asphalt extraction has been done a long time, both the organic and inorganic solvents. Various kinds of organic solvents has been tested on natural asphalt extraction, for example, kerosene [4], hexane [5], TCE and n-propyl bromide [6]. The use of solvents that have not been able to get $100 \%$ of asphalt from asbuton rock and it does not match with porosity of asbuton rock.

Carbonate minerals is the most mineral in asbutonrock [8]. Inorganic solvents became the next choice to be the extraction of asphalt from asbuton rock, one of which is $\mathrm{HCl}$ solution [7]. Use of $\mathrm{HCl}$ solution aims to dissolve carbonate solids $\left(\mathrm{CaCO}_{3}\right.$ and $\left.\mathrm{MgCO}_{3}\right)$ in asbuton rock. However, the use of $\mathrm{HCl} 30 \%$-wtsolution as a highly corrosive strong acid will produce a lot of hazardous waste, it can not take place in a sustainable manner and uneconomical. Therefore, both extraction methods were difficult to implement on an industrial scale.

Weak acid solution can be used to replace $\mathrm{HCl}$ solution, such as formic acid, acetic acid, and carbonic acid. These acids are less corrosive than $\mathrm{HCl}$. Formic acid and acetic acid have been used to dissolvecarbonate solids[8,9,10,11]. Its nature as weak acid has a distinct advantage because it is easily dissociate in water and has a large ionic capacity to facilitate its reaction with carbonate solid[12,13].For carbonic acid, itcan made by $\mathrm{CO}_{2}-\mathrm{H}_{2} \mathrm{O}$ system. Previous studies have demonstrated this system can dissolve carbonate solids $[12,13,14,15,16,17]$. Dissolution of carbonate solids can be improved by using ultrasonically assisted extraction. The use of ultrasound in solid-liquid extraction was perfomed in many materials to improve extraction rate, such as dissolution of phosphate [18], dissolution of magnesia [19], and dissolution of colemanite 
[20].

In this study, the main objective are dissolve carbonate solids to get asphalt and compare performance of several weak acid. Process parameter are temperature, acid concentration, $\mathrm{NaCl}$ concentration, and time. The asbuton rock and asphalt from extraction were analyzed qualitively by using Fourier-Transformed Infrared (FTIR) analysis.

\section{Method and Materials}

Raw material used in this study was asbuton rock. Asbuton rock was provided from the Lawele, Buton Island, Sulawesi Tenggara. Asbuton rock was crushed to have diameter of $2 \mathrm{~mm}$ and then heated at $180^{\circ} \mathrm{C}$. Asbuton rock used in this experiment was analyzed by SNI 03-3640-1994 and ASTM C25-06 to determine asphalt and mineral content. Organic acid used in this study were formic acid, acetic acid, and carbonic acid. Formic acid solution used was made from $\mathrm{HCOOH}$ 98\%-wt (Merck Tbk Indonesia) and distilled water. Acetic acid solution was made from $\mathrm{CH}_{3} \mathrm{COOH} 99 \%$-wt (Merck Tbk Indonesia) and distilled water. Carbonic acid solution was made by injecting $\mathrm{CO}_{2}$ to $\mathrm{NaCl}$ solution continously. $\mathrm{CO}_{2}$ with purity of $99 \%$. $\mathrm{NaCl}$ pure $(99 \%)$ from Merck Tbk Indonesia and distilled water were used for $\mathrm{NaCl}$ solution. Other solutions needed for preparation and analysis were $\mathrm{NaOH}$ solution, $\mathrm{HCl}$ solution, and TCE solution.

\subsection{Experimental Procedures}

Extraction experiments were carried out in a tubular glass batch reactor $(100 \mathrm{~mL})$ heated by constant temperature and equipped with stirrer, thermostatic bath, and thermocouple, as shown in Fig. 1. After $25 \mathrm{~mL}$ of formic acid or acetic acid solution was added to reactor,temperature was adjusted to desired value. For carbonic acid solution, $\mathrm{CO}_{2}$ was continously injected to $\mathrm{NaCl}$ solution for to maintain saturation condition. After 15 minutes, temperature was adjusted to desired value. Before temperature reached desired value, 2 gram of asbuton rock was added to the reactor while stirring at $500 \mathrm{rpm}$. For carbonic system, ultrasound effect will be used to change stirrer in previous reactor as shown in Fig. 2. Ultrasound probe was made from Chromtech with processor of $800 \mathrm{~W}$ and amplitude of $60 \%$.

At a certain time interval, asphalt was colleted immediatately from the solution. Furthermore, asphalt was heated and weighed to determine the amount of dissolved solids. Asphalt will be tested by standard ASTM C25-06 to estimate carbonate solids content and its density testing. FTIR analysis will be used to review the presence of carbonate solids qualitatively. Infrared spectra of asbuton rock and asphalt were recorded in the region of 4,000-400 $\mathrm{cm}^{-1}$ using $\mathrm{KBr}$ pellets. Extraction process for asbuton was tested under reaction conditions which were as follows: temperature from 25 to $100^{\circ} \mathrm{C}$, concentration of formic acid and acetic acid from 1 to $10 \mathrm{M}$, and $\mathrm{NaCl}$ concentration from 0 to $0.5 \mathrm{M}$.

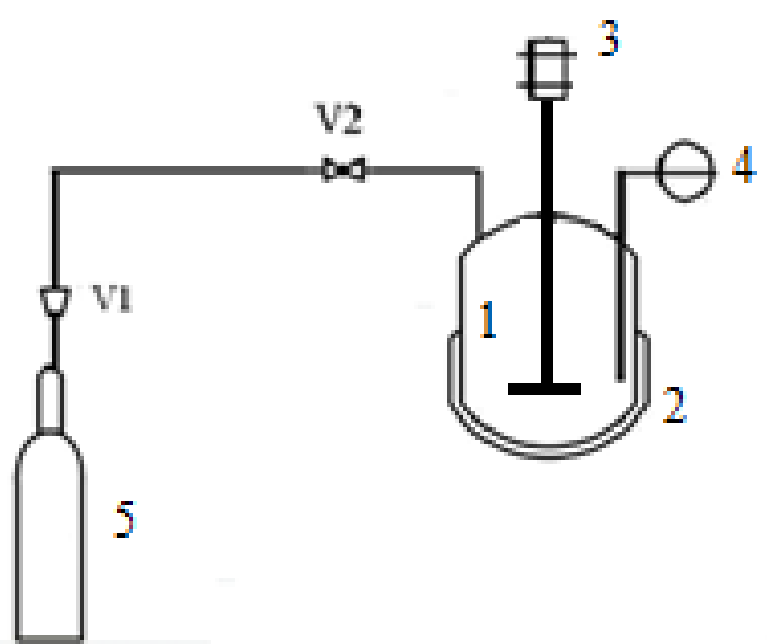

Figure 1. Schematic diagram of experimental apparatus for formic acid and acetic acid: 1. batch reactor; 2. thermostatic bath; 3. stirrer; 4 . thermocoupel; 5. $\mathrm{CO}_{2}$ tank; valve (v1 and v2)

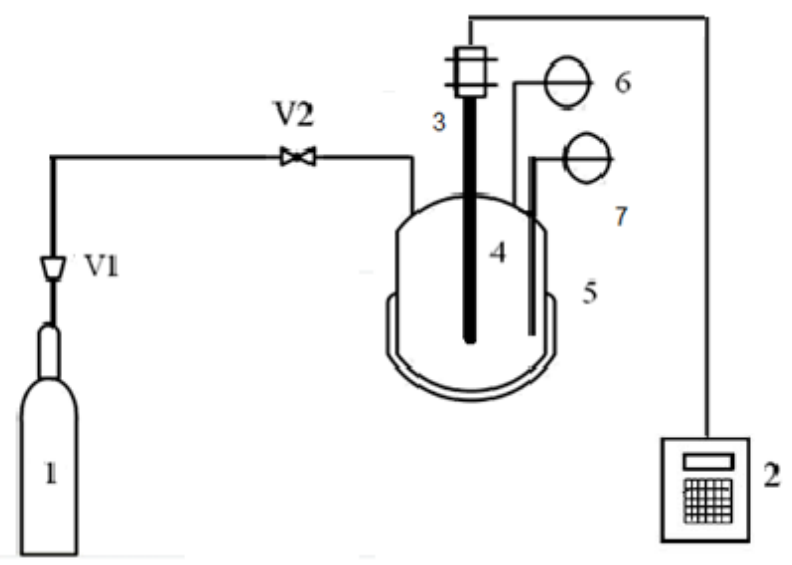

Figure 2. Schematic diagram of experimental apparatus for carbonic acid: 1. $\mathrm{CO}_{2}$ tank ; 2. Ultrasonic homogenizer; 3.Ultrasonic probe; 4. Reactor; 5. Thermostatic bath; 6. Pressure gauge ; 7. Thermocoupel

\section{Results and Discussion}

\subsection{Characteristic of Asbuton Rock}

Table 1 shows that the asbuton rock contains more mineral than asphalt. Asphalt contentin asbuton rock is $37.86 \%$. Average content of carbonate solids found in asbuton rockis $43.28 \%$. So, asbuton rock is contain $37.86 \%$ asphalt, $43.28 \%$ carbonate solids, and $18.86 \%$ other impurities. Other impurities could have been a solid $\mathrm{SiO}_{2}, \mathrm{CaSO}_{4}, \mathrm{CaS}$, and others. These solids have very low solubility in water and acid when compared with carbonate solids. This cause other impurities still remain and stick to asphalt. In previous study, asbuton rock from Lawele were previously found to contain mineral and asphalt [21]. Asphalt from asbuton rock has high viscocity because asphaltene content is high [21]. On the average, asbuton rock contain $30.08 \%$ asphalt and 9.92\% mineral [21]. The mineral in asbuton rock are $\mathrm{CaCO}_{3}$, $\mathrm{MgCO}_{3}, \mathrm{CaSO}_{4}, \mathrm{CaS}, \mathrm{H}_{2} \mathrm{O}, \mathrm{SiO}_{2}, \mathrm{Al}_{2} \mathrm{O}_{3}$, and $\mathrm{Fe}_{2} \mathrm{O}_{3}$ [21]. 
Table 1. Composition of Asbuton Rock

\begin{tabular}{cc}
\hline Component & Percentage \\
\hline Asphalt & $37.86 \%$ \\
Carbonate solids & $43.28 \%$ \\
Other impurities & $18.86 \%$ \\
\hline
\end{tabular}

\subsection{Dissolution Reactions}

In the extraction process, solubility of carbonate solids in weak acid can through chemical reaction process. The chemical reaction that occurs produces water, carbon dioxide gas, and salt. Previous studies have showed this reaction can be happen in this system $[9,10,11,12,13,14,15]$. Overall reaction for each solvent can be written as follows:

$$
\begin{aligned}
& \mathrm{CaCO}_{3(\mathrm{~s})}+2 \mathrm{HCOOH}_{(\mathrm{aq})} \leftrightarrow \mathrm{Ca}^{2+}{ }_{(\mathrm{aq})}+2 \mathrm{HCOO}_{(\mathrm{aq})}^{-}+\mathrm{CO}_{2(\mathrm{~g})}+\mathrm{H}_{2} \mathrm{O}_{(\mathrm{l})}
\end{aligned}
$$

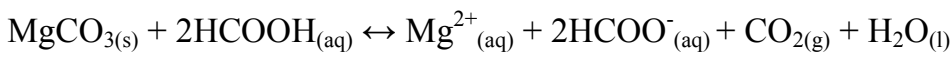

$$
\begin{aligned}
& \mathrm{CaCO}_{3(\mathrm{~s})}+2 \mathrm{CH}_{3} \mathrm{COOH}_{(\mathrm{aq})} \leftrightarrow \mathrm{Ca}^{2+}{ }_{(\mathrm{aq})}+2 \mathrm{CH}_{3} \mathrm{COO}_{(\mathrm{aq})}^{-}+\mathrm{CO}_{2(\mathrm{~g})}+\mathrm{H}_{2} \mathrm{O}_{(\mathrm{l})} \\
& \mathrm{MgCO}_{3(\mathrm{~s})}+2 \mathrm{CH}_{3} \mathrm{COOH}_{(\mathrm{aq})} \leftrightarrow \mathrm{Mg}^{2+}{ }_{(\mathrm{aq})}+2 \mathrm{CH}_{3} \mathrm{COO}_{(\mathrm{aq})}^{-}+\mathrm{CO}_{2(\mathrm{~g})}+\mathrm{H}_{2} \mathrm{O}_{(\mathrm{l})} \\
& \mathrm{CaCO}_{3(\mathrm{~s})}+\mathrm{H}_{2} \mathrm{O}_{(\mathrm{aq})}+\mathrm{CO}_{2} \leftrightarrow \mathrm{Ca}^{2+}{ }_{(\mathrm{aq})}+2 \mathrm{HCO}_{3 \text { (aq) }}^{-} \\
& \mathrm{MgCO}_{3(\mathrm{~s})}+\mathrm{H}_{2} \mathrm{O}_{(\mathrm{aq})}+\mathrm{CO}_{2} \leftrightarrow \mathrm{Mg}^{2+}{ }_{(\mathrm{aq})}+2 \mathrm{HCO}_{3}^{-}(\mathrm{aq})
\end{aligned}
$$

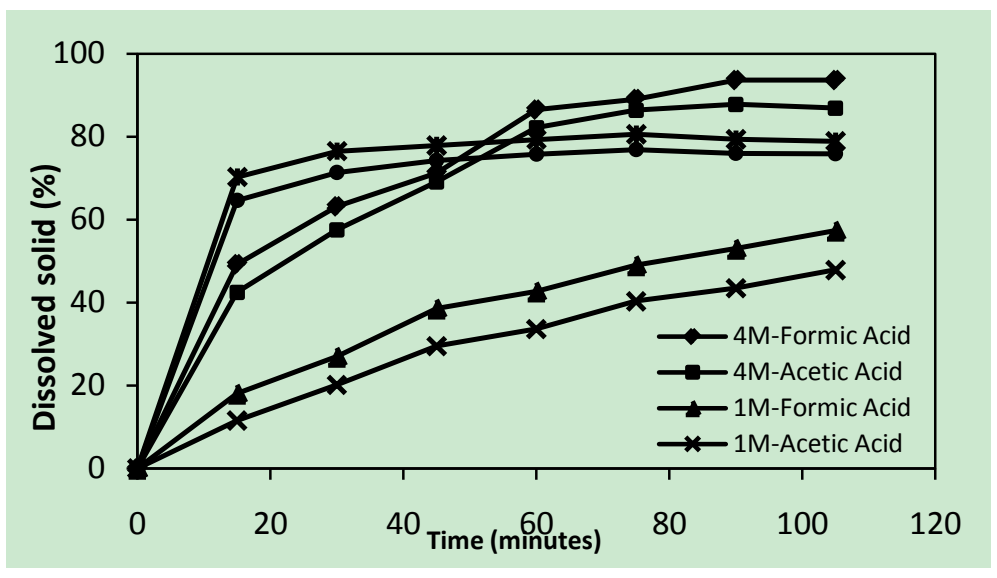

Figure 3. Effect of acid concentration in extraction using formic acid and acetic acid

\subsection{Extraction Using Formic and Acetic Acid}

Asbuton rock extraction was performed in acid concentration range of 1 to $10 \mathrm{M}$. In the range $0-60$ minutes, Figure 2 shows that acid concentration affects the solubility of carbonate solids in asbuton rock. High acid concentration increases the amount of carbonate dissolved solids. Dissolution of carbonate solids can be happen due to $\mathrm{H}^{+}$ions on the surface of solids react with carbonate solids. Higher acid concentration in the bulk phase will support the diffusion process of $\mathrm{H}^{+}$ions to the surface of carbonate solids, so that $\mathrm{H}^{+}$ions in the solid surface will increase $[12,13]$. In addition, the effectiveness of diffusion of $\mathrm{H}^{+}$ions can be increased compared to other ions if the acid concentration increased $[12,13]$. Complex reaction mechanisms can occur in low acid concentration, so that the solubility of carbonate solids decreases $[12,13]$. This is what causes carbonate solids can be dissolved more in high acid concentration.

In Fig.3, extraction time affects the amount of dissolved carbonate solids. Extraction time was strongly associated with reaction process. The longer extraction process will lead to more and more carbonate solids which converted into carbon dioxide, water, and salt. When the reaction is complete, extraction time will not affect the reaction. The longer extraction process will also affect the diffusion process. Increasing extraction time will lead to a lot of $\mathrm{H}^{+}$ ions diffuse from the bulk liquid phase to boundary layer of solid surface then adsorbed into it. In addition, the diffusion of $\mathrm{Ca}^{2+}, \mathrm{CO}_{3}^{2-}$, and other products also takes time from boundary layer to bulk liquid phase.

In Fig. 3, the difference results between formic acid and acetic acid are not too significant. More carbonate solids dissolved in formic acid than acetic acid. This is due to formic acid has higher strength and polarity than acetic acid. Higher strength acid causes $\mathrm{pH}$ solution to be low then it will support the diffussion of $\mathrm{H}^{+}$ions. Polarity of formic acid will make it easier soluble in water. In the range of 60-105 minutes, the amount of dissolved solids is more than carbonate content in asbuton rock. This is due to impurities, such as $\mathrm{CaSO}_{4}$ and $\mathrm{SiO}_{2}$, also dissolved in organic acids. However, more dissolved solids in solution of $4 \mathrm{M}$ compared to solution of $10 \mathrm{M}$. Dissolved solids can reach $93 \%$ for 
formic acid and $87 \%$ for acetic acid. This can occur due to impurities, such as $\mathrm{CaSO}_{4}$ and $\mathrm{SiO}_{2}$, less soluble in high concentrations $[22,23,24]$.

Previous studies have shown that temperature can increase the solubility of carbonate solids in acid solution $[11,12,13]$. It is also able to affect the solubility of carbonate solids in the asbuton rock extraction. Asbuton extraction was performed at various temperatures with acid solution of $4 \mathrm{M}$ for 15 minutes. In Fig.4, the solubility is proportional to temperature at $20-80^{\circ} \mathrm{C}$ temperature. Heating process resulted in more particle collision frequency and then it produces energy needed to reaction. This condition will increase reaction rate between carbonatesolids with formic acid and acetic acid. Increasing temperature also resulted in physical change of the asbuton rock. Asbuton rock can be softened by heating process. Asbuton rock can undergo softening due to the softening point of asbuton rock at $79.5^{\circ} \mathrm{C}$ [25]. Furthermore, contact area between solids and solution will expand then reaction rate will increase. In addition, the heating will reduce adhesion force between solids with asphalt, as was demonstrated in separation of non-conventional oil and sand [26]. Decreased adhesion force will cause solids separated from asphalt and then dissolution easily occur. Solubility of carbonate solids are unlikely to change in the temperature range of $80^{\circ} \mathrm{C}-100^{\circ} \mathrm{C}$. This shows the energy required for dissolution have been met when the temperature is $80^{\circ} \mathrm{C}$.

\subsection{Extraction Using Carbonic Acid}

Formic acid and acetic acid solution can dissolve the solid until more than $90 \%$ but these solution is difficult to be regenerated. If the solution can be regenerated then the process will be more economical and efficient. The carbonic acid solution from the system $\mathrm{H}_{2} \mathrm{O}-\mathrm{CO}_{2}$ can be an alternative because this solution can be regenerated easily by the heating process. The heating process can evaporate the dissolved $\mathrm{CO}_{2}$ so that it will be separated from the solution and can be used for the next process.

In the temperature of $70^{\circ} \mathrm{C}$ and the pressure of $1 \mathrm{bar}$, the extraction process is done by using the carbonic acid and ultrasonic effect. Fig. 5 shows that the carbonic acid solution can dissolve solids in asbuton rock. Some studies have shown that carbonate solids can be dissolved in this solution $[12,13,14,15,16,17]$. Compared to agitation rate of $500 \mathrm{rpm}$, the dissolution of carbonate solids can be improved by using ultrasound effect as seen in Fig. 5. The ultrasound wave has a large energy and it can produce cavitation bubble so that the high velocity turbulence motion of the fluid can appear near the surface of solid. This effect will improve heat and mass transfer to surface through boundary layer [27]. As the result, $\mathrm{H}^{+}$ion in the solution will diffuse easier to the surface and react with carbonate solids. Some studies have used ultrasound wave in the mineral dissolution process, like magnesia solid [20], phosphate [19], and colemanite [18].

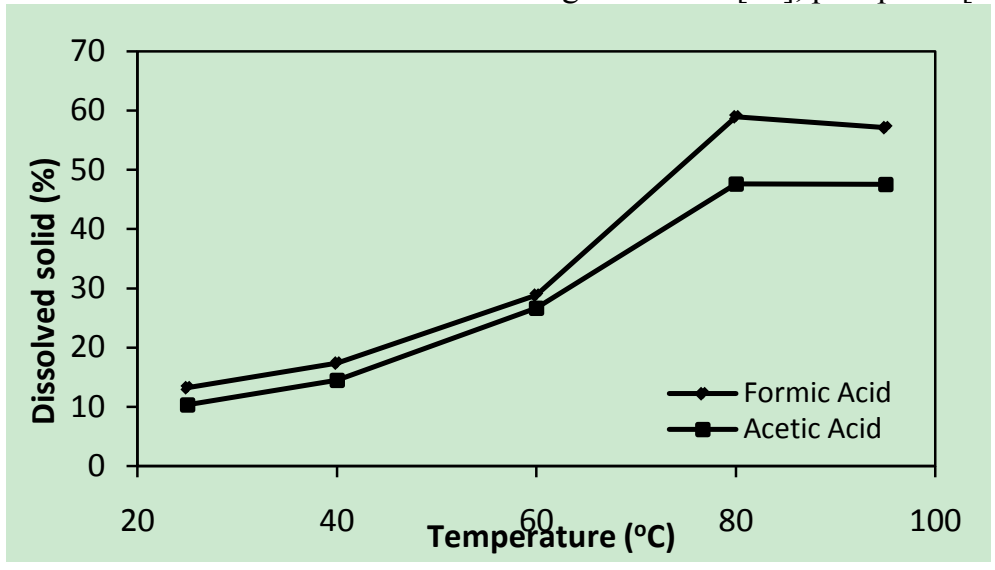

Figure 4. Effect of temperature in extraction using formic acid and acetic acid

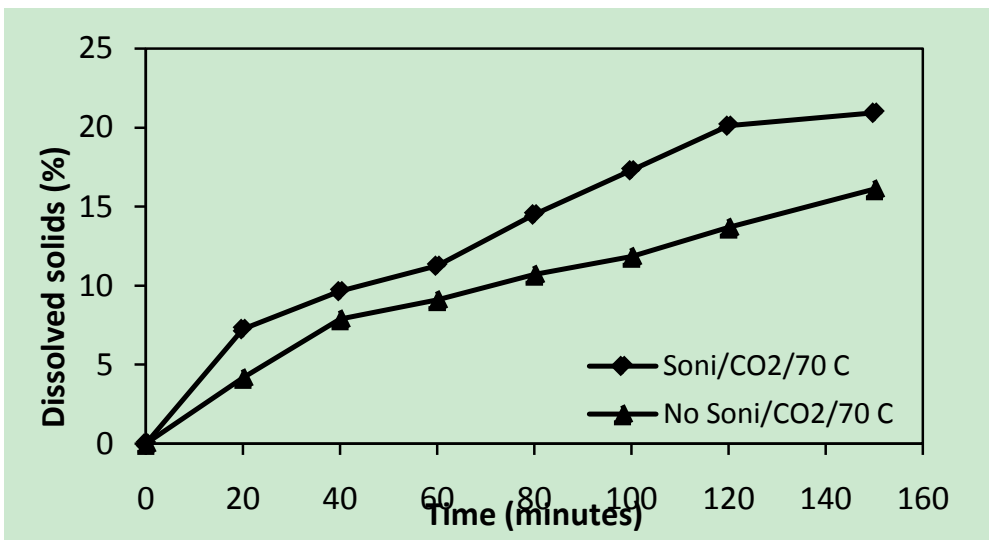

Figure 5. Effect of ultrasound in extraction using carbonic acid 


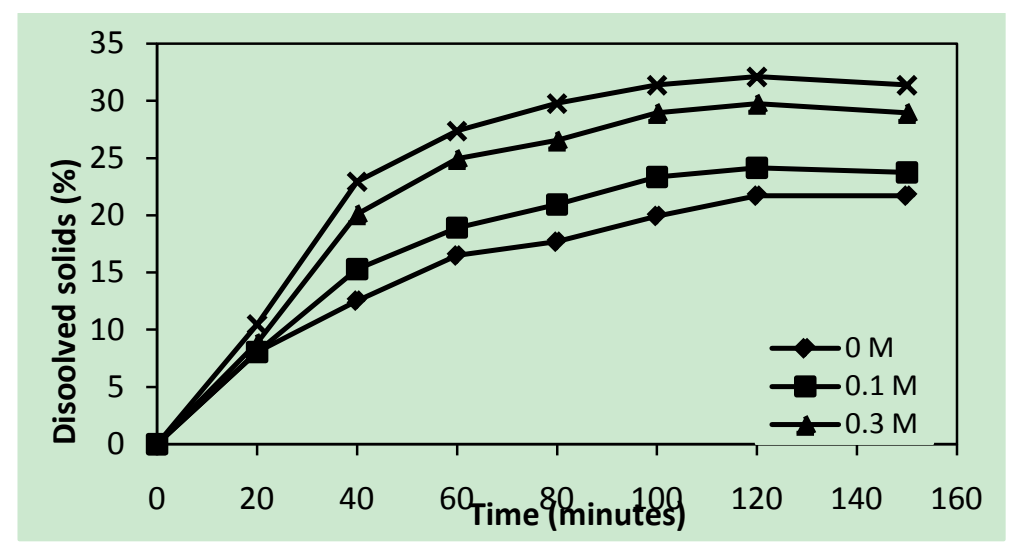

Figure 6. Effect of $\mathrm{NaCl}$ concentration in extraction using carbonic acid

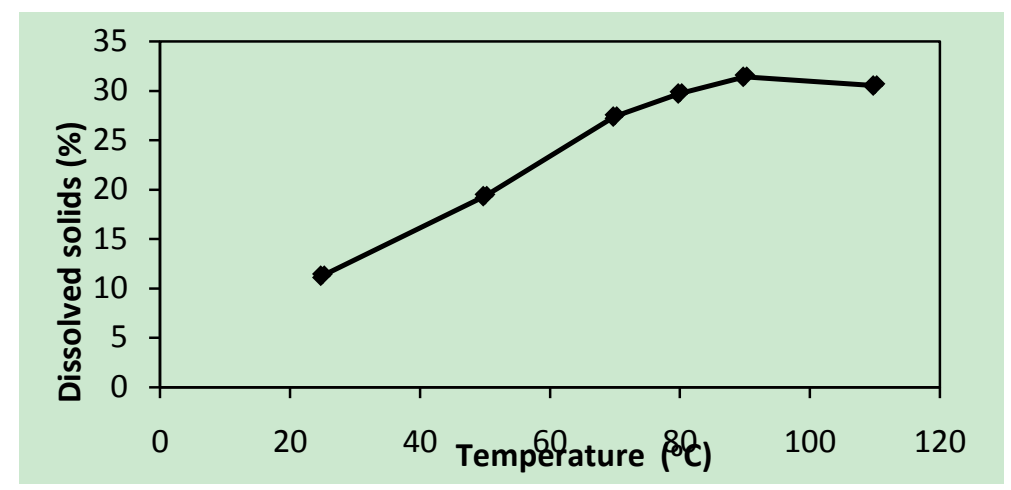

Figure 7. Effect of temperature in extraction using carbonic acid

The extraction using carbonic acid was performed with different concentration of $\mathrm{NaCl}$. In the $\mathrm{NaCl}$ concentration range from 0 to $0.5 \mathrm{M}$, Fig. 6 shows that the dissolution of solid in asbuton rock will improve when concentration of $\mathrm{NaCl}$ increases. Increasing concentration of $\mathrm{NaCl}$ will decrease the dissolution of $\mathrm{CO}_{2}$ in solution as resulted in previous studies about dissolution of $\mathrm{CO}_{2}$ in various saline solution $[14,15,16,17]$. Although $\mathrm{H}^{+}$ion will decrease because of the decrease of $\mathrm{CO}_{2}$ dissolution, increasing salt concentration can also increase ionic strength in the solution. Increasing ionic strength in the solution can ease carbonate solids to be dissolved so that the amount of dissolved carbonate acid will increase. Ellis [14], Duan et al [17], and Coto [15] found out that the dissolution of $\mathrm{CaCO}_{3}$ increases in the $\mathrm{NaCl}$ concentration range from 0 to $1.25 \mathrm{M}$. In the concentration range until $0.5 \mathrm{M}$, the solid can be dissolved until more than $30 \%$. Though this percentage is less than the use of formic acid and acetic acid, this process is sufficient to reduce the amount of carbonate solids in asbuton rock. The asphalt from this extraction process then can be used as the asphalt mixture in the road construction.

Temperature effect on the dissolution of carbonate solids from asbuton rock in carbonic acid solution is similiar to the result that have been explained before. The process temperature is variated from $25^{\circ} \mathrm{C}$ to $110^{\circ} \mathrm{C}$ in the pressure of 2 bar. The temperature becomes important variable in mineral extraction process, including the asbuton rock. In the range of 25 to $80^{\circ} \mathrm{C}$, the solid dissolution increases as the raise of temperature as shown in Fig. 7. The heat given to the system will give energy to increase reaction rate and soften asbuton rock. Asbuton rock that become soft will expand contact area between solution and solids. On the other hand, the maximum temperature for this condition is $80^{\circ} \mathrm{C}$ and increasing temperature until more than $80^{\circ} \mathrm{C}$ will decrease the amount of dissolved solids. This condition is caused by domination of $\mathrm{CO}_{2}$ dissolution effect in the solution. Higher temperature in constant pressure will make the $\mathrm{CO}_{2}$ dissolution decreases while the $\mathrm{pH}$ of the solution increases. After that, the low $\mathrm{pH}$ will make carbonate solids difficult to be dissolved. The effect of the temperature in the $\mathrm{CO}_{2}$ dissolution have been demonstrated by some authors $[13,14,15,16,17]$.

\subsection{Specific Gravity Testing}

Minerals contained in asbuton rock cause its specific gravity value reaches 1.56 , as shown in Table 2 . Table 2 shows that there wasreduction of specific gravity between asbuton rock and asphalt products. A reduction in specific gravity values indicate that carbonate solids dissolved in this solution. The specific gravity of asphalt by using formic acid has the closest value to specific gravity of petroleum asphalt. This indicates that more solids dissolved in formic acid than acetic acid or carbonic acid. Little dissolved solids in carbonic acid caused its specific gravity has the biggest value among other asphalt products. However, specific gravity of asphalt products is still higher than petroleum asphalt. This shows that the persistence of solids contained in asphalt. 
Table 2. Specific gravity of some components

\begin{tabular}{ccc}
\hline Components & Specific Gravity & Solvent \\
\hline Asbuton Rock & 1.56 & - \\
Petroleum asphalt & 1.034 & - \\
Asphalt-1 & 1.14 & Formic acid \\
Asphalt-2 & 1.25 & Acetic acid \\
Asphalt-3 & 1.34 & Carbonic acid \\
\hline
\end{tabular}

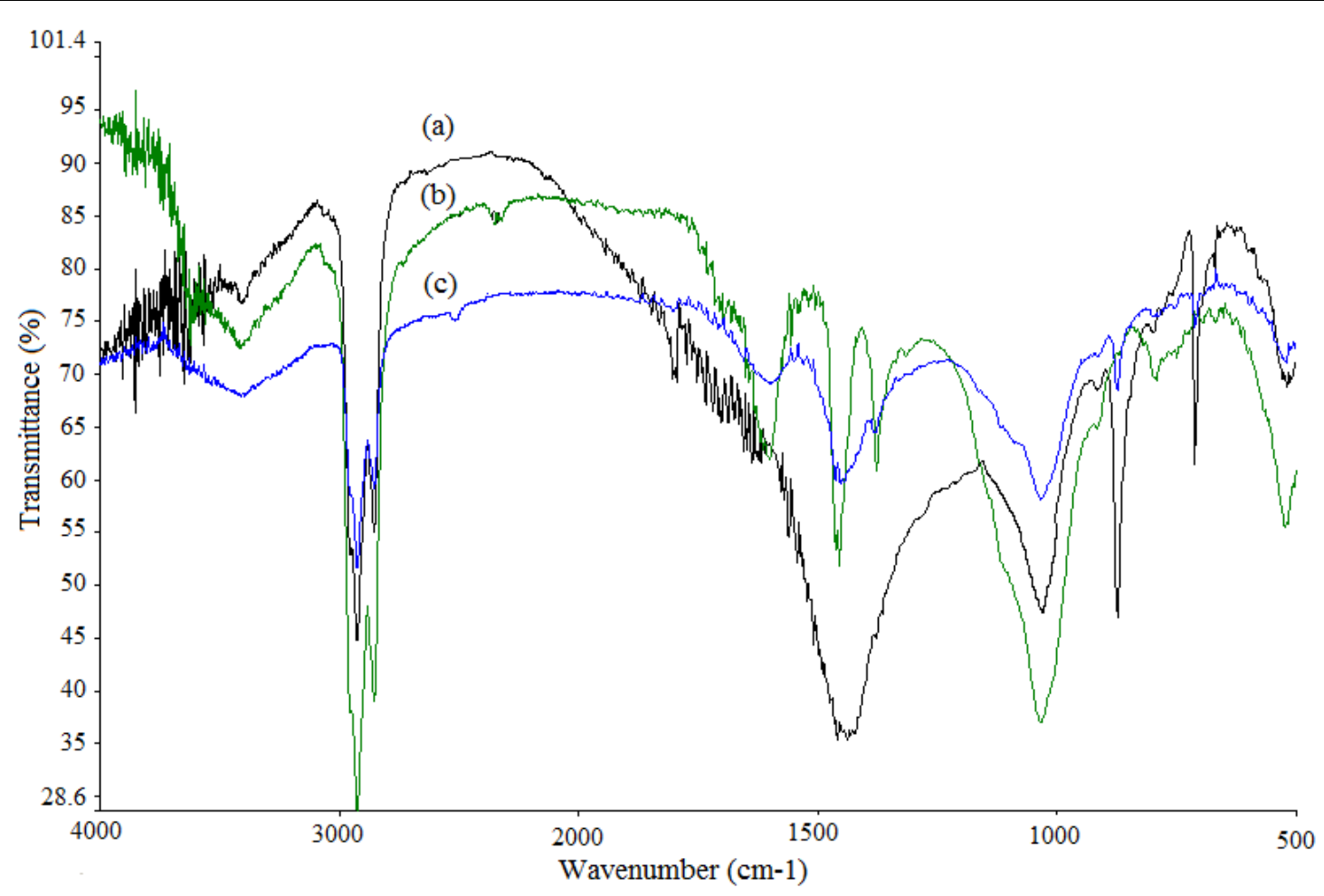

Figure 8. FTIR spectra of asbuton rock (a), asphalt product using formic acid (b), and asphalt product using carbonic acid (c)

\subsection{FTIR Analysis}

FTIR testing identified the presence of asphalt, carbonate, silica, gypsum, and other impurities in the asbuton rock and asphalt product. The first testing was performed on asbuton rock as shown in Fig.8(a). The results of spectra in the wavenumber range of $500-4,000 \mathrm{~cm}^{-1}$. In Fig.8(a), there is a strong absorbance at wavenumber $2,924 \mathrm{~cm}^{-1}, 2,855 \mathrm{~cm}^{-1}$, $1,458 \mathrm{~cm}^{-1}, 1,033 \mathrm{~cm}^{-1}, 874 \mathrm{~cm}^{-1}, 711 \mathrm{~cm}^{-1}$, and $515 \mathrm{~cm}^{-1}$.

The absorbance for the $-\mathrm{CH}_{3}$ group at about $2,924 \mathrm{~cm}^{-1}$ is common in asphalt. This may be due to $-\mathrm{CH}_{3}$ substituents on aromatics rings in asphalt. Asphalt and all the fractions show the absorbances at about $2,855 \mathrm{~cm}^{-1}, 1,601 \mathrm{~cm}^{-1}, 1,458 \mathrm{~cm}^{-1}$, and $1,376 \mathrm{~cm}^{-1}$ can be attributed to $\mathrm{C}-\mathrm{H}$ stretching in $-\mathrm{CH}_{3}$, $\mathrm{C}=\mathrm{C}$ stretching, $\mathrm{C}-\mathrm{H}$ deformation in $-\mathrm{CH}_{2}$ and- $\mathrm{CH}_{3}$, respectively. This spectra similiar to FTIR spectra of asphaltene [28,29].

Strong absorbance at $1,458 \mathrm{~cm}^{-1}$ also shows the characteristics of calcium carbonate and magnesium carbonate. Similarly, the absorbance in the region around $874 \mathrm{~cm}^{-1}$ and $712 \mathrm{~cm}^{-1}$ which indicates the presence of that compound as in [30]. Absorbance shows the $\mathrm{C}-\mathrm{O}$ bond in the $\mathrm{CO}_{3}^{-2}$ as a characterization of the existence of carbonate mineral compound.

Absorbance in the region around $1,088 \mathrm{~cm}^{-1}$ and $515 \mathrm{~cm}^{-1}$ indicate the presence of $\mathrm{Si}-\mathrm{O}$ bonds in $\mathrm{SiO}_{2}$ as a characterization of the existence of solid silica as in [30]. In the region 3,600-4,000 $\mathrm{cm}^{-1}$, indicating the presence of $\mathrm{C}-\mathrm{H}$ bonds in aromatic compounds and $\mathrm{O}-\mathrm{H}$ in the presence of impurities in the form of water or hydrate. Thus, it can be concluded that the asbuton rocks contain asphalt components, carbonate solids, silica solids, and others.

The second of FTIR testing was performed on asphalt products using formic acid and carbonic acid. The results of spectra shown in Fig. 8(b) and 8(c) with the range of $500-4,000 \mathrm{~cm}^{-1}$. In Fig. 8(b), the strong absorbance can be seen at wavenumber of $2,924 \mathrm{~cm}^{-1}, 2,855 \mathrm{~cm}^{-1}, 1,600 \mathrm{~cm}^{-1}$, $1,453 \mathrm{~cm}^{-1}, 1,376 \mathrm{~cm}^{-1}, 1,033 \mathrm{~cm}^{-1}$, and $515 \mathrm{~cm}^{-1}$. In Fig. 8(c), the strong absorbance can be seen at wavenumber $2,924 \mathrm{~cm}^{-1}$, $2,855 \mathrm{~cm}^{-1}, 1,600 \mathrm{~cm}^{-1}, 1,453 \mathrm{~cm}^{-1}, 1,376 \mathrm{~cm}^{-1}, 1,034 \mathrm{~cm}^{-1}$, $874 \mathrm{~cm}^{-1}, 711 \mathrm{~cm}^{-1}$ and $515 \mathrm{~cm}^{-1}$.

In Fig. 8(b) and 8(c), absorbance at the region of 
$3,600-4,000 \mathrm{~cm}^{-1}$ indicated the presence of hydroxyl group $(\mathrm{O}-\mathrm{H})$ and $\mathrm{N}-\mathrm{H}$ groups. Absorbance at about $2,924 \mathrm{~cm}^{-1}$ shows the aliphatic groups of $\mathrm{C}-\mathrm{H}$ bond in- $\mathrm{CH}_{3}$ groups are common to asphalt components. It is possible for the $-\mathrm{CH}_{3}$ on aromatic rings contained in component of asphalt. While the absorbance around $2,855 \mathrm{~cm}^{-1}, 1,600 \mathrm{~cm}^{-1}, 1,458 \mathrm{~cm}^{-1}$, and $1,376 \mathrm{~cm}^{-1}$ can be attributed to $\mathrm{CH}-\mathrm{CH}_{3}$ strain, the double bond of aromatic strain $\mathrm{C}=\mathrm{C}$, and deformation $\mathrm{CH}-\mathrm{CH}_{2}$ and $-\mathrm{CH}_{3}$. The absorbance at $2,924 \mathrm{~cm}^{-1}$ and 2,855 $\mathrm{cm}^{-1}$ were higher than results of asbuton rock spectra. This suggests that high asphalt content components in the samples tested.

In Fig. 8(b), the absence of large peak at $1,458 \mathrm{~cm}^{-1}$ region, as in asbuton rock spectra, indicated that it is not the existence of carbonate solids in asphalt product after extraction using formic acid. Moreover, the absence of strong absorbance in the wavenumber of $711 \mathrm{~cm}^{-1}$ and 874 $\mathrm{cm}^{-1}$ as shown also supports the absence of carbonate solids in asphalt extraction. In contrast, Fig. 8(c) shows absorbances at $874 \mathrm{~cm}^{-1}$ and $711 \mathrm{~cm}^{-1}$ so that carbonate solids are still contained in the asphalt product. In Fig. 8(b) and 8(c), strong absorbances at $1,033 \mathrm{~cm}^{-1}$ and $515 \mathrm{~cm}^{-1}$ indicated the presence of $\mathrm{SiO}_{2}$ compounds as same as asbuton rock spectra. Thus, it can be concluded that extraction process has been successful in carbonate dissolution of asbuton rock. However, silica solids remaining in the asphalt product.

\section{Conclusion}

Asbuton rock extraction using weak acid capable of dissolving carbonate solids. Extraction process using formic acid and acetic acid are affected by acid concentration, temperature, and time. Increased acid concentration and time will increase the amount of dissolved solids. However, a very high acid concentration, such as $10 \mathrm{M}$, will reduce the amount of dissolved solids. This is due to very high concentration will inhibit the solubility of other solids, besides carbonate solids. Increasing temperature will also increase the solubility of solids up to a certain limit.

Asbuton rock extraction using carbonic acid is able to dissolve carbonate solids. Increasing temperature and concentration of $\mathrm{NaCl}$ up to $0.5 \mathrm{M}$ will increase the solubility of solids. Ultrasound effect was used to increase the solubility of solids, as was performed by previous studies. Carbonic acid weaker than formic acid or acetic acid resulted in the amount of dissolved solids less than before. However, this study suggests that the carbonate solids in asbuton rock can be reduced.

Solubility of solids can be evidenced by the reduction of specific gravity. All asphalt products have a specific gravity smaller than asbuton rock. Furthermore, FTIR analysis showed that there was no carbonate solids in asphalt products after extraction using formic acid. FTIR analysis also showed that there was still carbonate solids after extraction using carbonic acid.

\section{Acknowledgements}

We thank the Indonesian Directorate General of High Education for funding that contributed to this work.

\section{REFERENCES}

[1] Suaryana, N. (2007). Analisis faktor-faktor yang dapat mendorong kegagalan dalam pelaksanaan asbuton. Pusat Penelitian dan Pengembangan Jalan dan Jembatan, Departemen Pekerjaan Umum. 3-10.

[2] Badan Pusat Statistik. (2010). Statistik Sulawesi Tenggara Dalam Angka Tahun 2010. Badan Pusat Statistik Provinsi Sulawesi Tenggara. Bab VI, 320-321.

[3] Affandi, F. (2006). Hasil Pemurnian Asbuton Lawele Sebagai Bahan Pada Campuran Beraspal Untuk Perkerasan Jalan. Jurnal Jalan-Jembatan, vol.3 (3), 6-28.

[4] Sayono. (2000). Paten : Proses Ekstraksi untuk Pemurnian Aspal dengan menggunakan Pelarut Organik. Indonesia Aplikasi Paten, ID 0004877.

[5] Purwono,S., Muhrachman, B., Yulianti, D. T., dan Suwati. (2005). Koefisien Perpindahan Massa pada Ekstraksi Aspal Buton dari Kabungka dan Bau-Bau dengan Pelarut n-heksan. Forum Teknik, vol.29, 40-49.

[6] Gardiner, M., Nelson, J.W. (2000). Use of Normal Propyl Bromide Solvents for Extraction and Recovery of Asphalt of Cements. NCAT Report 00-06, 2-7.

[7] Lisminto. (1996). Paten : Proses Pembuatan Aspal Murni dan Komposisi Aspal Modifikasi. Indonesia Aplikasi Paten, ID 010445.

[8] Nierode, D.E., Williams, B.B. (1971). Characteristics of acid reaction in limestone formations. Society of Petroleum Engineers Journal, vol.251, 406-418.

[9] Fredd, C.N., Fogler, H.S. (1998). The kinetics of calcite dissolution in acetic acid solutions. Chemical Engineering Science, vol.53(22), 3863-3874.

[10] Nasr-El-Din, Lynn, J.D., Taylor, K.C. (2001). Lab testing and field application of a large scale acetic acid-based treatment in a newly developed carbonate reservoir. SPE International Symposium on Oilfield Chemistry, 10-17.

[11] Lacin,O., Donmez,B., Demir,F. (2004). Dissolution kinetics of natural magnesite in acetic acid solutions. International Journal Mineral Process, vol.75, 91-99.

[12] Sjoberg, E.L., Rickard, D.T. (1983). The influence of experimental design on the rate of calcite dissolution. Geochim. Cosmochim. Acta 47, 2281-2286.

[13] Morse, W., and Arvidson, R.S. (2002). The dissolution kinetics of major sedimentary carbonate minerals. Earth-Science Reviews, vol.58, 51-84.

[14] Ellis, A.J.(1963). The solubility of calcite in sodium chloride solutions at high temperatures. American Journal of Science, vol.261, 259-267. 
[15] Coto, B., Martos, C., Pena, J.L., Rodriguez, R., Pastor, G. (2012). Effects in the solubility of $\mathrm{CaCO}_{3}$ : Experimental study and model description. Fluid Phase Equilibria, vol.324,1-7.

[16] Pokrovsky, O.S., Golubev, S.V., Schott, J., (2005). Dissolution kinetics of calcite, dolomite and magnesite at $25^{\circ} \mathrm{C}$ and 0 to 50 atm $\mathrm{pCO}_{2}$. Chemical Geology 217, 239-255.

[17] Duan Z. and Li D. (2008) Coupled phase and aqueous species equilibrium of the $\mathrm{H}_{2} \mathrm{O}-\mathrm{CO}_{2}-\mathrm{NaCl}-\mathrm{CaCO}_{3}$ system from 0to $250^{\circ} \mathrm{C}, 1-1000$ bar with $\mathrm{NaCl}$ concentrations up to saturation of halite. Geochim. Cosmochim. Acta, vol.72, 5128-5145.

[18] Okur, H., Tekin, T., Ozer, A.K., Bayramoglu, M. (2002). Effect of ultrasound on the dissolution of colemanite in $\mathrm{H}_{2} \mathrm{SO}_{4}$. Hydrometallurgy, vol.67, 79-86.

[19] Tekin, T. (2002). Use of ultrasound in the dissolution kinetics of phosphate rock in $\mathrm{HCl}$. Hydrometallurgy, vol.64, 187-192.

[20] Mesci, A.K., Sevim, F. (2006). Dissolution of magnesia in aqueous carbon dioxide by ultrasound. International Journal of Mineral Processing, vol.79, 83-88.

[21] Siswosoebrotho, B.I., Tumewu, W., Kusnianti, N. (2005). Laboratory Evaluation Of Lawele Buton Natural Asphalt In Asphalt Concrete Mixture. Proceedings of the Eastern Asia Society for Transportation Studies, vol.5, 857 - 867.

[22] Baruah,M.K.,Gogoi,P.C., Kotoky,P. (2000).Sulphate behaviour from dissolution of gypsum in organic acids. Fuel, vol.79, 211-216.

[23] Bennet, P.C, Melcer, M.E., Siegel, D.I., Hasset, J.P. (1988). The dissolution of quartz in dillute aquaous solutions of organic acid at $25^{\circ} \mathrm{C}$. Geochimica et Chosmochimica Acta, vol.52, 1521-1530.

[24] Knauss, K.G., Wolery, T.J. (1987). The dissolution kinetic of quartz as a function of $\mathrm{pH}$ and time at $70^{\circ} \mathrm{C}$. Geochimica et Chosmochimica Acta, vol.52, 43-53.

[25] Buton Asphalt Indonesia. "Bitumen Testing”. www.bai.co.id /tools_bitumen_testing.htm(Accessed : 10 Juni 2012).

[26] Long J, Xu Z, Masliyah J. (2005). On the role of temperature in oil sands processing, Energy Fuels, vol.19(4),1440-1446.

[27] A. Kannan, S.K. Pathan. (2004). Enhancement of solid dissolution process, Chem.Eng. J. vol.102, 45-49.

[28] León-Bermúdez, A.-Y., Salazar. (2008). Synthesis and Characterization of The Polystyrene - Asphaltene Graft Copolymer by FT-IR Spectroscopy. CT\&F - Ciencia, Tecnología y Futuro, vol.3, 157-167.

[29] Yoon, S., Bhat, D.S, Lee, W., Lee Y.H, Jeong, S.Y. (2009). Separation and characterization of bitumen from Athabasca oil sand. Korean J. Chem. Eng., 26(1), 64-71.

[30] Reig, B.F., Adelantado, G., Moreno,M. (2002). FTIR quantitative analysis of calcium carbonate (calcite) and silica (quartz) mixtures using the constant ratio method. Talanta, vol.58, 811-/821. 